\title{
De stethoscoop: meer dan alleen een statussymbool
}

Collega-docenten van andere faculteiten vinden ons als medisch docenten bevoorrecht omdat wij te maken hebben met gemotiveerde en getalenteerde studenten die in grote getale en in hoog tempo de studie afronden. En als we willen, kunnen we zelfs selecteren aan de poort. Het beroepsperspectief als arts wordt als een belangrijke reden voor deze motivatie gezien. Voor deze aanstaande dokters is een belangrijk moment aangebroken als bij een van de klinische practica in het begin van de opleiding de stethoscoop kan worden gehanteerd. Het lichamelijk onderzoek is een van de essentiële onderdelen in de beroepsuitoefening van artsen en instructie hiervan derhalve een wezenlijk onderdeel van de opleiding.

Praktisch klinisch onderwijs kent vele varianten bij de diverse opleidingen. In doelstelling verschillen ze echter niet: training in anamnese, communicatieve vaardigheden, klinisch redeneren of klinische probleemanalyse en in de fysische diagnostiek. Het is van alle tijden dat ervaren clinici zich zorgen maken over de kwaliteiten van de jonge generatie op het gebied van lichamelijk onderzoek. Middels wetenschappelijk onderzoek is dit inderdaad geobjectiveerd. Hierbij wordt veelal gebruik gemaakt van simulatiemodellen, waarbij auscultatie van het hart behoort tot de favoriete te toetsen onderdelen. De uitkomsten worden echter nog al eens gerelativeerd, omdat de geluidsopnames niet voldoende overeen zouden komen met de echte klinische praktijk.

Daarom is een recente Amerikaanse studie interessant, waarin de vaardighe- den op het gebied van onderzoek van het hart bij 860 personen werden getest in een meer realistische setting. ${ }^{1}$ Met een gestandaardiseerde opstelling kon de integrale interpretatie van meerdere bevindingen (naast auscultatie gegevens van inspectie en palpatie van het hart en hals met videoopnames van reële patiënten) worden getest. Opnieuw bleek bijna de helft van de ouderejaars studenten geneeskunde, maar ook van huisartsen- en internisten-in-opleiding en stafleden niet competent op dit gebied. Gedurende het opleidingstraject werd het dus niet beter. Een begeleidend editorial, aanstekelijk enthousiasmerend geschreven en derhalve zeer lezenswaardig, benadrukt het belang van nauwkeurig lichamelijk onderzoek en pleit voor hernieuwde aandacht in het onderwijs en in de dagelijkse praktijk. ${ }^{2}$

Er zijn geen redenen om aan te nemen dat de situatie in ons land beter is. Precies weten we het niet, want hoe vaak zien we onze coassistenten en specialisten-in-opleiding eigenlijk bezig met lichamelijk onderzoek? Hoe vaak laten we het voordoen en controleren we het? Als we al een KKB (korte klinische beoordeling)-formulier invullen, hoe vaak vullen we het onderdeel lichamelijk onderzoek dan eigenlijk in? Is het dan vreemd dat het zo slecht gesteld is met deze vaardigheden? Waarom klagen de studenten dat iedereen het op zijn eigen wijze doet? Hoe is het eigenlijk gesteld met onze voorbeeldfunctie op dit onderdeel van ons medisch handelen?

Zoals gezegd zijn de meeste studenten tijdens de studie erg enthousiast en leergierig, maar gaandeweg komen bij velen 
de twijfels over de waarde van het lichamelijk onderzoek, al of niet gevoed door hun begeleiders. Onderzoek met steeds meer verfijnde beeldvormende technieken lijkt het lichamelijk onderzoek op achterstand te zetten qua sensitiviteit en specificiteit. Het is erg verleidelijk zo'n aanvullend diagnostisch onderzoek aan te vragen en door anderen te laten uitvoeren met alle extra kosten, in plaats van zelf er wat meer energie in te steken. Fysisch diagnostisch onderzoek blijft dus van groot belang. Het is snel en goedkoop en leent zich voor het vervolgen van bevindingen in de loop van de tijd. Nog kortgeleden verscheen een onthutsende studie, waarin werd aangetoond dat herhaald en meer nauwgezet fysisch diagnostisch onderzoek bij acuut opgenomen patiënten bij een groot aantal leidde tot drastische wijzigingen in diagnostisch of therapeutisch beleid. ${ }^{3}$

Welke les moeten we hieruit trekken? We moeten het enthousiasme van onze jonge geneeskundestudenten die voor het eerst een stethoscoop hanteren en zich bekwa- men in het lichamelijk onderzoek, niet beschamen. We moeten realistisch zijn over de waarde, maar tegelijk niet verzaken de elementaire vaardigheden te onderwijzen en ons houden aan de gezamenlijke afspraken over de wijze van instructie. Niets is dodelijker dan dat elke docent, en we zijn met zeer velen, zijn eigen stokpaardjes berijdt. Dit betekent ook observeren en feedback geven, niet alleen bij de coassistenten, maar ook bij de specialisten-inopleiding. Alleen zo blijft de stethoscoop meer dan alleen een statussymbool.

\section{P.M.J. Stuyt}

\section{Literatuur}

1. Vukanovic-Criley JM, Criley S, Warde CM, et al. Competency in cardiac examination skills in medical students, trainees, physicians, and faculty. A multicenter study. Arch Intern Med 2006;166:6106.

2. Simel DL. Time, now, to recover the fun in the physical examination rather than abandon it. Arch Intern Med 2006;166:603-4.

3. Reilly BM. Physical examination in the care of medical inpatients: an observational study. Lancet 2003;362:1100-5. 